\title{
IMPROVING THE ABILITY OF WRITING SHOWS USING THE SCIENTIFIC LEARNING MODEL IN CLASS X STUDENTS OF SMK N 2 HILISERANGKAI
}

\author{
Eperiani \\ Mendrofa $^{1+}$ \\ ${ }^{1}$ Universitas \\ Fakultas Pendidikan Bahasa dan Sastra Indonesia \\ 'Email: epymend19@gmail.com.
}
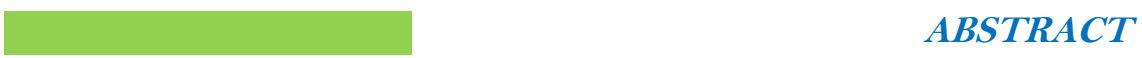

Article History

Received:

Revised:

Accepted:

Published:

Keywords

Ability, writing, short story,

scientific

\begin{abstract}
The purpose of this study was to determine the improvement in the ability to write short stories using the Scientific learning models in Class X Students of SMKN 2 Hiliserangkai. PTK (Classroom Action Research) models which consist of 4 stages, namely the planning, action, observation, and reflection stages.

Sources of research data for class X students of SMKN 2 Hiliserangkai City were 28 people and the data of this study were short story texts. Data collection uses test instructions to write short stories with specified themes and student activity observation sheets. Data analysis uses average calculations and final analysis qualitatively. The results showed that there was an increase in short story writing skills through the scientific learning model for students of class X OTKP of SMKN 2 in Hiliserangkai. This is evident from the learning results in the first cycle obtained an average of 70.21 with good categories and increased in the learning outcomes of the second cycle with an average of 80.14 with a very good category. Student activities include aspects of discipline, responsibility, cooperation and independence with the category active enough in the first cycle to increase to be very active in the second cycle in the learning material describing the structure of the text, life values, and structure of short story builders.
\end{abstract}

Preface

The success of the Indonesian language learning process in schools is not only seen in the achievement of the success of the students but is also determined by the quality of the teachers who teach in the classroom. Indonesian language learning which is managed by Indonesian language teachers needs quality. Quality learning can certainly be achieved when learning is managed by qualified Indonesian teachers. Such qualification for Indonesian language teachers naturally originates from the educational process managed by the Education Personnel Education Institute (LPTK) including in this case the Gunungsitoli IKIP as a producer of prospective teachers. Quality LPTK certainly needs to be realized in order to produce competent educators in accordance with the demands of Law Number 14 of 2005 concerning teacher professionalism. According to this law, teachers are professional educators who have competence (pedagogic, academic, personal, and social). LPTKs as producers of quality teachers in addition to having to realize these laws also play a role in transmitting teaching competencies with a renewable learning model to educators in schools. This task is carried out by education (lecturers) at the LPTK through collaborating activities with educators in schools in achieving learning objectives at certain educational levels.

Indonesian learning curriculum 2013 is text-based. That is, learning activities refer to text mastery with the demands of its achievement, namely the ability to write text according to its type, such as writing short stories. Text-based learning is intended to achieve high proficiency in mastering the use of language structures. This is because the level of thinking (literacy) of our students nationally, according to the achievement of the language PISA level in 2021 is only at level 3 on average. 
while other countries in Southeast Asia are already on it (see PISA results 2009; 2012). In addition, the results of students who have not been proud of the Indonesian Language National Examination based on KTSP and 2013 Curriculum (2017) and the results of the TIMMS study, that most Indonesian students are only able to answer intermediate level problems (as much as 95\%) while the students' ability to answer questions those that require thinking (high reasoning) are still inadequate (only about 5\%) (Kemdikbud, 2013: 2). Therefore, the level of children's literacy should be guided through a culture of writing, especially developing what they see, hear and think so that it is possible to generate creativecritical ideas in the form of higher student literacy.

Students' low literacy (thinking) ability cannot be denied as a result of the Indonesian language learning model that the teacher chooses and applies to the learning process. Therefore, it is necessary to develop Indonesian language proficiency through the ability to write texts. The development of text-based writing skills is an effort to foster and develop students' thinking patterns in a fast, coherent, critical, and creative manner. At this level, students are required to write sentences with simple ideas in a clear order and use their own words. Furthermore, at the secondary school level students are required to develop writing in the form of text based on more complete signs such as text structure and topic development in addition to word selection and use of sentences as well as language styles. In addition, according to the competency standards of graduates in the field of Indonesian studies, writing orientation is related to effective writing of various types of texts in various contexts and the goal of achieving communicative learning (Bachman, 1990: 85). Learning writing skills must be based on students' mastery or possession of adequate language rules and high contextual sensitivity. Even simple writing would not be possible without knowledge of simple language rules and good insight into the story environment. However, the reality shows that the results of students' writing skills learning are still far from expectations. There are still many students who are less able to put ideas into writing properly, develop themes into scripts and coherent written content even though they have attended Indonesian language lessons since elementary school.

The results of observations on the implementation of Indonesian language learning show that various efforts to train students to write have been mostly done after the explanation of writing ends. As a result, learning to write becomes a long theoretical explanation and writing practice is rarely done or if it is done it becomes a task / homework which do not necessarily get intensive guidance in realizing writing. The impact of learning to write at home makes learning outcomes less effective and meaningless for students because the process of pouring ideas into text is not directly experienced by students. As part of the learning process which is managed by the teacher through "building context and studying the model" which should clarify in writing but because the results of writing are not corrected together as an effort to "construct the text together and construct the text independently" because the next day learning has to continue the next material.

Writing activities are indeed not easy things for students at school. According to some teachers, the main difficulty lies in the activity of expressing main ideas or ideas into a coherent series of sentences so that they are written and easy to read. It is possible that students' writing is not well developed, because when they start writing, what they have thought experiences a deadlock. The Information given by the teacher shows those students tend to be less able to express ideas and clutter in their thinking. It is related to the implementation of the 2013 curriculum, that obstacles reappear when starting to write various types of texts and this is also experienced by some teachers who seem not yet ready to express the learning process of writing text skillfully and professionally. Writing skills 
require regular writing practice and paying attention to the components in realizing the product of the ability to write short stories. Mastery of writing components, such as content (the suitability of the title with the content), text structure, choice of words, the use of effective sentences and language style and mechanics have not been fully realized. Writing story texts (short stories) is part of the skills demand in high school (Wiratno, 2014). Therefore, the possession of proficiency in writing this text needs to be pursued properly by the Indonesian language teacher, especially in teaching students to write.

The ability to write is a person's skill in productive language because it produces a product, namely writing. Murray and Moore (2009: 31) state that the ability to write is a complex and creative process for a person in producing writing from a series of words into sentences and paragraphs using written language. The ability to write is a person's skill in arranging language and order of thoughts in writing so that they can be communicated successfully to readers. This is as Rivers (in Hadley, 1993: 290-292) argues that the ability to write is a person's ability to practice writing naturally by utilizing real contexts. Specifically, the definition, that writing ability involves two things, namely the ability to receive and use. The ability to use relates to activities that emphasize the use of language codes for the purpose of communicating ideas, ideas in written form. Byrne (in Yulistio, 2012: 25) states that writing skills are a result of one's efforts in realizing and collectivity of linguistic knowledge and processing ideas through thoughts that are reflected in the form of writing so that they can be communicated to readers successfully. Thus, it can be said that the ability to write is the skill of the writer (student) in conveying ideas, ideas or messages as an accumulation of thoughts and experiences by using a series of language symbols into written form.

In order for someone to be skilled in writing, it is necessary to practice intensively, persistently, and diligently in realizing good written products. Ideris (2013: 4-24) emphasizes that if the ability to write becomes an interesting and fun activity, one must be able to develop thinking patterns in writing. In getting used to writing, it is necessary to practice regularly. Ma Crimmon (1984: 10-11) describes the stages of writing, which includes preparing a plan, making a draft Writing and development and revising written products to make them more perfect. Richards and Renandya (2002: 316-319) add three external stages in the writing process as classroom activities carried out by teachers, namely responding (sharing), evaluating, and post-writing. Based on some of the opinions above, it can be described that the writing stages consist of planning (pre-writing), drafting, revision, editing, review, evaluation, and complete writing (post-writing).

Short stories are a form of literary work. Zainurrahman (2011:37) suggests a short story, which is a narrative text that is fictional and tells the story of events and conflicts (conflicts), and instills moral and entertaining values. Edgar Allan Poe (in Abrams, 1999: 286287) adds that the short story has a "short" character, that is, it is read in one sitting, about between half an hour to two hours and is limited by certain peculiarities and has a single effect. Based on the expert opinion above, it can be stated that the short story is a fictional short narrative text with a simple single plot that tells an event with the aim of entertaining or instilling moral values. Garry (2011: 44) and Margaret Lucke (1999: 4-5) agree that a good short story usually has building elements, namely theme, plot / plot, characterization, setting, point of view, and writing style. In relation to the ability to write, that the ability to write short stories is a person's ability or ability to express ideas, feelings, and thoughts through the form of short fictional narrative writing (short stories) which aims to entertain and convey moral messages. In the process of learning to write short stories, students can learn to write interesting and memorable life experiences to be narrated and shared with others in the form of short story writing. Writing short stories is useful in developing ideas and experiences and 
can inspire others when reading them. Through short stories students can convey the meaning of life through planting the moral values of life.

Learning to write short stories is currently not able to build students' creativity to regularly write as a creative skill. Learning to write short stories is still limited to learning the theory of writing short stories and has not yet familiarized students to directly work literature. Because of the theoretical nature of learning, students have difficulty writing ideas, short story ideas properly and systematically. In learning to write short stories, students have not been directed to think critically, creatively, and systematically in developing story ideas into short story writing. This happens because the learning approach used is still teacher centered, with learning still focusing on providing knowledge about short stories. Learning is one-way and causes students to get bored quickly and less creative. As a result, learning to write short stories is less interesting. Learning to write short stories usually begins with the teacher giving a special theme. When choosing a short story writing theme, students seem to be limited by the teacher's thinking. This causes students to have difficulty pouring ideas, thoughts into short stories. In addition, teachers do not pay attention to the needs of students in learning to write short stories, especially in assessing writing. Assessment of students' writing is only seen from the final result of the writing. Therefore, teachers need to provide steps in writing their experiences in the form of short story writing by explaining the basic aspects of assessing short stories so that they become guidelines in writing short stories such as paying attention to the content, short story text structure, word choice, use of language style, and mechanical aspects.

On the other hand, learning to write short stories will be successful if it is done using good learning steps that are easy for students to follow. In this case the teacher needs to choose an approach or method and learning model that is also relevant to learning to write short stories. In the 2013 curriculum, learning to write short stories can be implemented using a special model in Indonesian language learning, namely the scientific approach. This model aims to achieve students' competence in Indonesian language optimally. This learning model can develop the concept of Pedagogical Content Knowledge, which is a model that combines the understanding of the content of learning materials (content knowledge) and understanding how to educate (pedagogical knowledge) that blend into one. The main flow of the pedagogical model of the genre is carried out through 4M steps (Building context, Examining the Model, Guided Constructing, and Self-Construction). Activities to get knowledge (KI-3) can be done through learning with a scientific-based approach (scientific) in the form of observing, questioning, gathering information, reasoning, and communicating. Skills development (KI-4) is continued with guided construction steps and independent construction.

(3) Consider communication and use of language in learning activities using language as a means of communication as Indonesian is used for discussions and presentation assignments of Indonesian language subject matter, (4) Compiling a list of activities in learning (learning activities must be interesting and use a real communication context). Activities such as games, storytelling, songs, rhymes, pictures, drama, role playing, dialogue, and presentations can easily engage students in Indonesian language and material, and (5) Compile an assessment (the assessment must be comprehensive) covering all aspects of learning, namely language competence and material knowledge. Assessment should help students demonstrate the material and language they have learned. Assessment in short story writing is carried out on aspects of the relevance of the content to the theme, text structure, word choice (diction), sentence use (language style), and mechanics (spelling and handwriting). (a) Content (content of the material). Content in this case is to increase 
knowledge and understanding of the material. The delivery of material is carried out by the teacher when explaining the material and when evaluating the results of practicum and running dictation, (b) Communication (communication). Communication in this case is to improve students' skills in using language to communicate. Students' communication skills are honed when discussing the results of practicum and running dictation, (c) Cognition (Cognition). Cognition in this matter is to develop students' thinking skills. Students' thinking skills are developed through practicum activities, group discussions, and running dictation. Practical activities include ordering data writing and dividing class dividing into small groups, and (d) Culture (culture). Culture in this case is to increase students' understanding of themselves and others so that they can raise an attitude of care and responsibility. This activity is carried out during apperception, namely the teacher provokes students with questions about their daily lives related to the material.

Based on the above problems, it is necessary to conduct classroom action research, to describe the increase in the ability to write short stories using a combined learning model of a scientific approach in class X OTKP SMKN 2 Hiliserangkai Odd Semester 2020/2021.

\section{METHOD}

This research uses the Classroom Action Research (CAR) method which includes the stages of planning (plan), implementation (act), observation (observe), and reflection (reflect) This research uses the Kemmis \& Taggart model emphasizes the discovery process (Hopkin's, 1993: 48) . At the planning stage, activities are carried out to compile a Learning Implementation Plan (RPP), write short stories, prepare materials, prepare guidelines for observing student activities, and prepare learning media. At the stage of implementing the action, covering the introduction, core, and closing uses a three-approach model. At the observation stage, observations were made on changes in student activity in the process and the results of learning to write short stories. In the reflection stage, the teacher describes all the processes that have been and have not been carried out as an effort to improve problems that have not been resolved. The research data were in the form of short stories written by 28 students of class X OTKP SMKN 2 Hiliserangkai.

The research was conducted in the odd semester of 2020/2021, namely in October 2020. Data collection used test and observation techniques. The data collection tools used were (1) short story writing test guidelines based on several aspects, including content, structure, diction, use of sentences and language styles, and mechanics, (2) guidelines for observing student activities covering aspects of discipline, responsibility, cooperation , independence. Analysis of the data on the ability to write short stories using the mean formula and qualitative assessment ranges to determine student activity in the Indonesian language learning process. Benchmark Indicators of success, those students are declared successful if they achieve an individual score of at least 75 and classically if as many as $80 \%$ of students achieve a score of 75 . Student activity is said to increase if the aspects of discipline, responsibility, independence, and cooperation change from inactive to active or very active. 


\section{RESULTS AND DISCUSSION \\ Research Result}

The results of the research on the Improvement of the Ability to Write Short Stories using a learning model of three pedagogical approaches to genre, scientific, and CLIL in class X OTKP SMKN 2 Hiliserangkai Odd Semester 2020/202 1 on 28 people were carried out in two cycles as follows.

a. Learning Results Cycle I

Learning cycle 1 is carried out in four stages, namely (1) planning stage, learning preparation is carried out including (1) preparation of lesson plans (RPP) for learning materials to write short stories. Learning to write short stories using a three-approach learning model was carried out 3 times with the material (a) short story writing components, (b) finding the values of life in short stories Sulaiman went to Tanjung China, (c) determined the structure of the short story text and the building elements of the short stories Sulaiman left to Tanjung China and one meeting (d) compiling a framework and short story text production with the theme of affection, (2) compiling learning materials, compiling student worksheets, (4) compiling learning media and teaching aids, (5) developing guidelines for observing activities students, and (6) compiling guidelines for assessing students writing short stories, (2) The implementation stage, the learning process is carried out according to the learning tools that have been designed through the learning implementation process with stages (a) introduction, (b) core learning, and (c) closing, (3) Observation stage, carried out in collaboration with lecturers and teachers. Observing the learning process carried out by students, namely the teacher observing student activities. The results of the learning process are that in general students are quite active in learning in terms of discipline, responsibility, cooperation, and independence in learning to write short stories, and (4) the Reflection Stage, that at the end of cycle 1 learning activities can be described that the learning process can be carried out by good but have not reached the indicators of success so learning is continued in cycle II by preparing some materials and better plans.

From the learning outcomes of students' short story writing skills in cycle I, it can be described in the following table.

Table 1.Results of the Ability to Write Cycle 1

\begin{tabular}{|c|c|c|l|}
\hline No. & Aspect (Score) & $\begin{array}{c}\text { Averag } \\
\text { e }\end{array}$ & Category \\
\hline 1 & Contents (25) & 17,5 & Good \\
\hline 2 & Structure (20) & 14,7 & Good \\
\hline 3 & Diction (20) & 14,5 & Good \\
\hline 4 & Style Sentences Language (25) & 16,7 & Good \\
\hline 5 & Mechanical (10) & 6,8 & Enough \\
\hline 6 & Ability Writing short stories & 70,2 & Good \\
\hline
\end{tabular}

From the table above it can be seen that the learning outcomes of students' short story writing skills in the first cycle are categorized as good with an average value of 70.2. This shows that the students' short story writing skills still need to be improved in the process and learning outcomes. Based on each aspect of the ability to write short stories, it was found that (1) the content aspect was categorized as good with an average value of 17.5 , (2) the text structure aspect was categorized as good with an average of 14.5, (3) the aspect of the category was good with a mean of $14.5,(4)$ the sentence aspect of the style is good with 
a mean of 16.7 , and the mechanical aspect is categorized as sufficient with an average of 6.8 and still needs to be improved.

b. Learning Results Cycle II Learning cycle 1

It is carried out in four stages, namely (1) the planning stage, the preparation of learning is carried out including (1) the preparation of a lesson plan (RPP) for learning materials to write short stories. Learning to write short stories using a three-approach learning model was carried out 3 times with the material (a) determining the language and structure aspects of the short story text "Waiting for the long resonance of the soul", (b) finding the values of life, text structure, and the building blocks of the short story 'Robohnya Surau We ', (c) determine the aspects of writing short stories' The collapse of our Surau', and one meeting $(\mathrm{d})$ compile the framework and production of short stories with the theme of affection, (2) compile learning materials, (3) compile student worksheets, (4) compiling instructional media and teaching aids, (5) compiling guidelines for observing student activities, and (6) preparing guidelines for assessing students' short story writing, (2) The implementation stage, the learning process is carried out according to the learning tools that have been designed through the learning implementation process with stages (a) introduction, (b) core learning, and (c) closing, (3) Observation Stage, carried out in collaboration with lecturers and teachers. Observing the learning process carried out by students, namely the teacher observing student activities. The results of the learning process are that in general students are very active in learning in terms of discipline, responsibility, cooperation, and independence in learning to write short stories both in groups and classically, and (4) the Reflection Stage, that at the end of cycle II learning activities can be described that the learning process can be carried out well and achieve indicators of success so that the Classroom Action Research learning activities are ended. From the learning outcomes of students' short story writing skills in cycle II, it can be described in the following table. Table 2 Results of the Ability to Write a Short Story Cycle 2

\begin{tabular}{|c|c|c|c|}
\hline No. & Aspect (Score) & Average & Category \\
\hline 1 & Contents (25) & 19,96 & Good \\
\hline 2 & Structure (20) & 16,93 & Very good \\
\hline 3 & Diction (20) & 16,93 & Very good \\
\hline 4 & Sentence Style Language (25) & 18,75 & Good \\
\hline 5 & Mechanical (10) & 7,57 & Good \\
\hline 6 & Writing Skills Short story & 80,14 & Very good \\
\hline
\end{tabular}

From the table above, it can be seen that the learning outcomes of students' short story writing skills in cycle II are categorized as very good with an average of 80.14. This shows that the students' short story writing skills have improved from the previous learning cycle and the learning outcomes need to be maintained. Based on each aspect of the ability to write short stories, it was found that (1) the content aspect was categorized as good with a mean value of 19.96, (2) the text structure aspect was categorized as very good with an average of $16.93,(3)$ the aspect of the category was very good with an average of $16.93,(3)$ the sentence aspect of the language style is in a good category with a mean of 18.75 , and the mechanical aspect is in a good category with an average of 7.57 and still needs to be improved. 


\section{Discussion}

Based on the results of the study, it was found that there was an increase in the ability to write short stories using a combined learning model of three scientific approaches in class XI OTKP SMKN 2 Hilisrangkai students. This increase can be seen from the results of learning to write short stories to 28 students in the first cycle in the good category with a mean value of 70.2, increasing in the second cycle in the very good category with a mean value of 80.14. This is in accordance with the opinion of Wiratno (2014) that writing short stories is a requirement that students must achieve in learning Indonesian at various levels of education both in junior high and high school. Learning to write quality short stories must be based on various components of analytic assessment including content relevance, structure, diction, sentence style, and mechanics.

Based on the data on the results of the assessment of the ability to write short stories according to the aspects / components, it can be described that the mechanical aspects, namely spelling and handwriting, are still in the sufficient category in cycle I. This can be seen from the short stories written by students who still do not pay attention to spelling, such as writing the preposition 'di'. The strung together with the words that follow. For example at school, outside, at home, and there, this should be written at home, at school, there, and outside. The use of punctuation marks / to 1 , to 2 /, should be written / to- 1 , to- 2 /. The writing of standard words and loanwords that are still influenced by regional languages or are not correct occurs in the use of words such as sebua, disebua, girl, telephone, and only what should be written as a, disebuah, girl, telephone, and only. Besides that, there are errors in using words at the beginning of sentences such as the words / and / used to start a sentence. The use of punctuation /, / (comma) in a transitional word that starts a sentence as a link between sentences is also still happening, such as the word $/ / \ldots$ then .../ should be used at the beginning of a sentence such as "Then, .." Problems with this mechanical aspect in the second cycle the error rate has decreased.

This result still needs to be improved by carrying out writing exercises continuously by paying attention to good writing organization. This is as emphasized by MaCrimmon (1984: 10-11) that writing needs to be done with writing planning, writing products, and reviewing writing so that the short stories that are made are easily understood by readers. Besides that, a short story must be written with attention to the short story building elements as emphasized by Garry (2011: 44).

According to him, short story learning must pay attention to the intrinsic structure of the short story, which includes the theme and message, plot, characters and characterizations, settings, field points, and story writing style.

The combined learning model of the three approaches required by the 2013 curriculum in Indonesian language learning is able to lead students to write short stories carefully and systematically because of the scientific elements that language learning in terms of language content is studied at the same time using Indonesian. According to Coyle (2008), this learning is very appropriate because learning the language, in this case Indonesian, uses the communication tool in Indonesian. On the other hand, learning is presented with the stages of analyzing the context and modeling and constructing the text together and independently through scientific (scientific) learning steps so as to realize short story text products. 


\section{CLOSING}

\section{Conclusion}

Based on the results of the research and discussion, it can be concluded that there is an increase in the ability to write short stories using the three scientific approach learning model in class X OTKP SMKN 2 Hiliserangkai students in the process and learning outcomes. This can be. This is evident from the results of learning in the first cycle obtained a mean of 70.21 with a good category and an increase in the results of learning cycle II with an average of 80.14 with a very good category. Student activities include aspects of discipline, responsibility, cooperation and independence with the active category in cycle I increasing to being very active in cycle II in learning material describing the structure of the text, the values of life, and the structure of the short story building being studied.

\section{Suggestion}

Based on the research conclusions, several suggestions are put forward, namely (1) in learning to write quality short stories, teachers are expected to use learning models, namely genre pedagogy, scientific creatively in order to facilitate students in learning independently, responsibly, and in discipline as well as collaborating and (2) Students do more activities through regular practice so that their writing results are even better.

\section{References}

Abrams, M.H. 1999. A Glossary of Literary Terms, Seventh Edition. USA: Thomson Learning. Bachman, Lyle F. 1990. Fundamental Considerations in Language Testing. Oxford: Oxford University Press.

Coyle, Do. 2008. Content and Language Integrated Learning; Motivating Learners and Teachers. Http://blocs.xtec.cat/clilpractiques 1/fi les/2008/11/slrcoyle.pdf. Diakses tanggal 10 Oktober 2020.

Disher, Garry. 2011. Writing Fiction, An Introduction To The Craft. Australia: Allen\&Unwin. Djiwandono, Soenardi. 2008. Tes Bahasa Pegangan Bagi Pengajar Bahasa. Jakarta: PT Indeks.

Hadley, Alice Omaggio. 1993. Teaching Language in Context. Boston: Heinle \& Heinle Publishers.

Heaton, J.B. 1988. Writing English Language Tests. New York: Longman Group UK Limited.

Hopkins, David. 1993. A Teacher's Guide to Classroom Research. Philadelphia: Open University Press.

Ideris, Haderi. 2013. Pintar Menulis Cerpen: Cara Jitu Mendobrak Pintu Kesulitan Menulis. Banjarmasin: Dreammedia.

Jacobs, Holly L., et.al. 1981. Testing ESL Composition: A. Practical Approach. Massacheserttes: Newbury House Publishers, Inc.

Johnson, Elaine B. 2002. Contextual Teaching and Learning: What it is and why it's here to stay. Callifornia: Corwin Press, Inc.

Kementerian Pendidikan dan Kebudayaan RI. 2013. Bahasa Indonesia: Wahana

Pengetahuan untuk SMP/MTs Kelas

VII. Buku Siswa. Jakarta: Kementerian Pendidikan dan Kebudayaan.

Kementerian Pendidikan dan Kebudayaan RI. 2014. Buku Guru: Bahasa Indonesia Wahana Pengetahuan untuk SMP/MTs Kelas VII. Jakarta: Kementerian Pendidikan dan Kebudayaan. 
Latief, Muh. Adnan. 2002. "Pengembangan Bahan Ajar Kontekstual Bahasa Inggris SLTP Cawu 2 Untuk 6 Provinsi di Kalimantan dan Sulawesi”, Jurnal Penelitian Kependidikan, Tahun 12 Nomor 1, Juni.

McCrimmon, James M. 1984. Writing with a Purpose. USA: Houghton Mifflin Company.

Murray, Rowenna \& Sarah Moore. 2009.

The Handbook of Academic Writing, A Fresh Approach. New York: Mc-Graw Hill.

Nur, Muhammad. 2001. "Pengajaran dan Pembelajaran Kontekstual", Makalah Pelatihan TOT Guru Mata Pelajaran SLTP dan MTs, Juni.

Richards, Jack C. dan Willy A. Renandya. 2002. Methodology in Language Teaching,An Anthology of Current Practice. USA: Cambridge University Press.

Setyaningrum, Wahyu. 2010. Content and Language Integrated Learning (CLIL) sebagai Alternatif Pendekatan dalam Pembelajaran Matematika Berbahasa Inggris. http://staff.uny.ac.id/sites/default/fil es/penelitian/Wahyu/Setyaningrum, M.Ed./CLIL/semnas.pdf. Diakses tanggal 10 Oktober 2020.

Sevilla, Consuelo G, dkk. 1993. Pengantar Metode Penelitian. Terjemahan Alimuddin Tuwu. Jakarta: UI Press.

Satori. 2013. "Komponen Kompetensi Profesional Guru", Pendidikanku: Informasi Pendidikan Terkini. Http://sdnwonoue.blogspot.com/201 3/08.html. Diunduh, 27 April 2015.

Wiratno, Tri. 2014. "Pembelajaran Bahasa Indonesia berbasis Teks dalam Kurikulum 2013". Materi Pelatihan Instruktur Nasional Pembelajaran Bahasa Indonesia Berbasis Teks. Jakarta: Badan Pengembangan dan Pembinaan Bahasa.

Yulistio, Didi. 2012. "Pengaruh Strategi Pembelajaran dan Kemampuan Penalaran Terhadap Keterampilan Menulis", Disertasi Tidak Diterbitkan. Jakarta: UNJ.

Zainurrahman. 2011 Menulis: Dari Teori Hingga Praktik (Penawar Racun Plagiarimse). Bandung: Alfabeta. 